\title{
Incidence, diagnosis, treatment methods, and outcomes of clinically suspected venous thromboembolic disease in patients with COVID-19 in a quaternary hospital in Brazil
}

\author{
Incidência, diagnóstico, métodos terapêuticos e desfechos de eventos tromboembólicos \\ venosos em pacientes com COVID-19 em um hospital quaternário do Brasil
}

\author{
Marcela Juliano Silva Cunha' (D), Carlos Augusto Ventura Pinto', João Carlos de Campos Guerra', \\ Adriano Tachibana', Maria Fernanda Cassino Portugal ${ }^{1}$ (D), Leonardo José Rolim Ferraz', Nelson Wolosker,2
}

\begin{abstract}
Background: Prothrombotic states have been associated with viral infections and the novel Sars-COV-2 infection has been associated with elevated D-dimer levels, although no causal relation has been clearly established. Objectives: This study presents an epidemiological analysis of manifest VTE episodes in a group of patients hospitalized because of COVID-19. Methods: Medical records of patients who presented symptomatic deep vein thrombosis and/or pulmonary embolism in concomitance with confirmed COVID-19 were retrospectively studied. Demographic characteristics, prevalence of VTE, site of occurrence, D-dimer variation over time, management, and outcomes were analyzed. Results: During the study period, 484 confirmed cases of COVID-19 were admitted, 64 of which displayed VTE symptoms and 13 of which had confirmed symptomatic VTE(2.68\% of total sample and $20.31 \%$ of symptomatic cases). Most cases (76.92\%) occurred in intensive care. On the day attributed to VTE onset, D-dimer levels were over 3,000 ng/mL in 8 (80\%) patients, a significant increase from baseline admission levels $(p<0.05)$. A significant decrease was also observed in D-dimer values at hospital discharge $(p<0.05)$. All patients received pharmacological thromboprophylaxis and/or anticoagulation as indicated. Two deaths occurred during the study, both patients with severe comorbidities. At the end of our study protocol, nine patients had been discharged and two remained hospitalized, but had no signs of VTE worsening. Conclusions: VTE prevalence in hospitalized COVID-19 patients was 2.7\%, and higher in intensive care units. Early institution of prophylaxis and immediate full anticoagulation when VTE is diagnosed should be the goals of those who treat this kind of patient.
\end{abstract}

Keywords: thrombosis; thromboembolism; pulmonary embolism; coronavirus disease-19; death; drug therapy.

\begin{abstract}
Resumo
Contexto: Os estados pró-trombóticos têm sido associados a infecções virais. A nova infecção pela síndrome respiratória aguda grave do coronavírus 2 (SARS-CoV-2) sabidamente eleva os níveis de D-dímero, embora a relação causal não tenha sido bem estabelecida. Objetivos: Este estudo apresenta uma análise epidemiológica de episódios sintomáticos de tromboembolismo em um grupo de pacientes hospitalizados pela doença do novo coronavírus (COVID-19). Métodos: Foi realizada uma revisão retrospectiva de prontuários de pacientes internados por COVID-19 que apresentaram trombose venosa profunda e/ou embolia pulmonar sintomáticas. Foram avaliados os dados demográficos, a prevalência de tromboembolismo, a variação do D-dímero ao longo do tempo, o manejo e os desfechos. Resultados: Dos 484 casos confirmados de COVID-19 admitidos entre março e julho de 2020, 64 apresentaram sintomas de tromboembolismo, que foram investigados, e 13 tiveram tromboembolismo confirmado (2,68\% do total e 20,31\% dos sintomáticos). A maioria dos casos ocorreu em regime de terapia intensiva (76,92\%). Houve um aumento significativo no número de pacientes com D-dímero acima de $3.000 \mathrm{ng} / \mathrm{mL}$ no dia atribuído ao diagnóstico de tromboembolismo com relação aos níveis do momento da admissão (80\%, p < 0,05). Uma queda significativa de pacientes nesse limiar também foi observada no momento da alta $(p<0,05)$. Todos os pacientes receberam tromboprofilaxia ou anticoagulação conforme indicado. Houve dois óbitos na amostra, ambos pacientes com comorbidades severas. Ao fim do protocolo, nove pacientes receberam alta e dois permaneceram hospitalizados, mas sem sinais de piora. Conclusões: A prevalência de tromboembolismo em pacientes hospitalizados por COVID-19 foi de 2,7\%, sendo mais frequente em regime de terapia intensiva. A instituição precoce de profilaxia e anticoagulação imediata ao diagnóstico é primordial nesse grupo de pacientes.
\end{abstract}

Palavras-chave: trombose; tromboembolismo venoso; embolia pulmonar; COVID-19; óbito; tratamento farmacológico.

How to cite: Cunha MJS, Pinto CAV, Guerra JCC, et al. Incidence, diagnosis, treatment methods, and outcomes of clinically suspected venous thromboembolic disease in patients with COVID-19 in a quaternary hospital in Brazil. J Vasc Bras. 2021;20:e20200203. https://doi.org/10.1590/1677-5449.200203

${ }^{1}$ Hospital Israelita Albert Einstein - HIAE, São Paulo, SP, Brasil

${ }^{2}$ Universidade de São Paulo - USP, Faculdade de Medicina, São Paulo, SP, Brasil.

Financial support: None.

Conflicts of interest: No conflicts of interest declared concerning the publication of this article.

Submitted: December 07, 2020. Accepted: February 15, 2021.

The study was carried out at Hospital Israelita Albert Einstein (HIAE), São Paulo, SP, Brazil.

Copyright $(2021$ The authors. This is an Open Access article distributed under the terms of the Creative Commons Attribution License, which permits unrestricted use, distribution, and reproduction in any medium, provided the original work is properly cited. 


\section{INTRODUCTION}

Venous thromboembolism (VTE) is a serious health concern, affecting up to 1 in 1,000 adults worldwide each year. Epidemiological studies have shown that prior to the institution of consistent in-hospital prophylaxis, 55 to $60 \%$ of all VTE cases were related to hospitalizations, being diagnosed either while still hospitalized or during the first 90 days after the patient's discharge. ${ }^{1}$ Deep venous thrombosis (DVT) is the greatest cause of preventable in-hospital deaths, with an annual mortality rate in Brazil of 2.09 per 100,000 inhabitants. ${ }^{2,3}$

Viral outbreaks can lead to hypercoagulable states and deaths due to VTE, strokes and hemorrhagic disorders. ${ }^{4}$ In the last months of 2019, a new coronavirus (severe acute respiratory syndrome coronavirus 2 or SARS-CoV-2) was identified as the agent of a pneumonia outbreak that quickly spread, reaching pandemic status and being named COVID-19. ${ }^{5}$

The Sars-COV-2 infection has been associated with elevated levels of D-dimer (DD), although no causal relation has been clearly established. ${ }^{6}$ Further studies are needed to determine if there is a positive significant association. Comprehensive knowledge of the relationship between COVID-19 and VTE enables better decision-making concerning thrombotic and hemorrhagic risks.

Little is known about the pathogenic mechanism through which SARS-CoV-2 is able to trigger the chain reaction of immunologic, inflammatory, and coagulation responses in human patients.

To date, studies that have analyzed the clinical and epidemiological characteristics of patients with VTE related to infection by SARS-CoV-2 have reported conflicting results. ${ }^{7-11}$

We present an epidemiological analysis of COVID-19 patients who were admitted to a quaternary hospital in Brazil and presented clinically symptomatic thromboembolic events with an analysis of the diagnostic methods, management, and outcomes of these cases.

\section{METHODS}

This is a retrospective study of the medical records of patients who presented with symptomatic VTE (deep vein thrombosis [DVT] and/or pulmonary embolism [PE]) concomitant with SARS-CoV-2 infection, treated at Albert Einstein Jewish Hospital, São Paulo, Brazil, between March and July of 2020. This study was approved by the institution's Ethics Committee under protocol 30809720.9.0000.0071, report number 4.126.297.
The sample only included patients in whom COVID-19 was confirmed by a laboratory test (positive real-time PCR for COVID-19).

In cases in which a physician's clinical assessment suggested presence of DVT, patients were subjected to a duplex scan of the limb and additional computed pulmonary angiotomography or angiogram to rule out PE. When imaging studies were positive for DVT or PE, patients were included in the study. Clinical suspicion for DVT was defined by pain and/or swelling of one or more limbs, with or without high VTE probability according to the Wells criteria. ${ }^{12}$

For included patients, the incidence of VTE, demographic characteristics, DVT and PE site, DD variation over time, anticoagulation regimen, additional treatment methods, and outcomes were analyzed.

\section{Statistical analysis}

Categorical data are expressed as absolute frequencies and percentages and continuous data are expressed as means with standard deviations and minimum-maximum values. DD values above $3,000 \mathrm{ng} / \mathrm{mL}$ were compared according to time of observation using generalized estimating equations (GEE), assuming exchangeable correlations between times. The Bonferroni method was used to identify at which times differences occurred. Tests were performed using a $5 \%$ significance level.

\section{RESULTS}

During the period of this study, 484 confirmed cases of COVID-19 were admitted to our service. Sixty-four patients (13.22\%) presented some form of clinical suspicion of DVT and underwent a duplex scan.

Thirteen of the patients evaluated $(2.68 \%$ overall, $20.31 \%$ of those subjected to imaging evaluation) presented VTE: there were five cases of concomitant DVT and PE; six cases of isolated DVT; and two cases in which PE was identified but no thrombus was visible in the limbs. For this incidence and sample, the $95 \%$ confidence interval ranges from 1.3 to $4.1 \%$; and the precision for this sample is $1.45 \%$.

The population, clinical, and imaging characteristics of all cases of concomitant COVID-19 and symptomatic VTE are presented in Table 1. The average age was 62.7 years, ranging from 40 to 97 years (median 62). Seven patients $(53.8 \%)$ were male.

Over one third of the sample presented two or more preexisting medical conditions, the most common of which was overweight, noted in $76.9 \%$ of patients. Other common comorbidities were dyslipidemia $(58.8 \%)$ and systemic arterial hypertension (SAH) (38.5\%).

All of the patients were treated as in-patients. In one case, the patient had been hospitalized for 
Table 1. population characteristics and number of preexisting medical conditions.

\begin{tabular}{lcc}
\hline \multicolumn{1}{c}{ Baseline Characteristics } & $\mathrm{N}$ & $\%$ \\
\hline Gender & & \\
Male (\%) & 7 & 53.8 \\
Female (\%) & 6 & 46.2 \\
BMI kg/m ${ }^{2}$ (Mean) & & $50.7 \pm 6.6$ \\
$<18.5$ (\%) & 1 & 7.7 \\
18.5-24.9 (\%) & 2 & 15.4 \\
$25-29.9$ (\%) & 6 & 46.2 \\
$30-34.9$ (\%) & 2 & 15.4 \\
$35-39.9$ (\%) & 1 & 7.7 \\
$>40$ (\%) & 1 & 7.7 \\
\hline Preexisting Conditions & $\mathrm{N}$ & $\%$ \\
\hline 0 & 2 & 15.3 \\
1 to 2 & 2 & 15.3 \\
$>2$ & 9 & 69.2 \\
\hline \multicolumn{1}{c}{ Preexisting Conditions } & $\mathrm{N}$ & $\%$ \\
\hline Dyslipidemia & 7 & 53.8 \\
SAH & 5 & 38.5 \\
DM & 4 & 30.8 \\
Cancer & 3 & 23.1 \\
Smoking & 2 & 15.4 \\
Thrombophilia & 2 & 15.4 \\
COPD & 1 & 7.7 \\
CAD & 2 & 15.4 \\
Previous VTE Episode & 1.7 \\
\hline
\end{tabular}

three months prior to manifestation of COVID-19 symptoms, in palliative care due to a neoplasm and advanced age.

Only 1 of the 13 patients had a prior personal history of VTE; two were current smokers and all others denied current smoking habit.

Eleven patients $(84.6 \%)$ presented with signs suggestive of COVID-19 on the admission CT-scan. In 10 cases, the patients' initial clinical status was considered severe and they were immediately admitted to an intensive care unit (ICU).

One of the three patients who were initially stable ultimately required transfer to an ICU bed due to clinical deterioration associated with VTE. Although the other two were diagnosed with DVT, they remained stable and did not require respiratory support (one of these was the aforementioned patient in palliative care).

Among the 10 patients in intensive care, seven required orotracheal intubation $(63.6 \%)$; six needed hemodialysis (54.5\%); and one needed extracorporeal membrane oxygenation $(9.1 \%)$ for respiratory stabilization.

Six of the 11 DVTs diagnosed through duplex scan were in the lower limbs $(54.5 \%)$ and five were in upper limbs (45.5\%). The upper limb DVTs all occurred in the right arm and were all associated with current or previous use of central venous catheters.
In the lower limbs, there was one case of DVT in the popliteal vein, two cases in the tibial veins, and three cases in femoral veins. An upper limb DVT was the culprit in just one of the cases of PE that occurred in association with DVT (20\%).

Computed tomography angiography was the diagnostic method for six cases out of seven PE patients. In the remaining patient, the diagnosis was made by catheter angiography and echocardiogram. PEs were bilateral in six cases $(85.7 \%)$. Trunk involvement was observed in one case, segmental involvement in three cases, and the remaining four cases were subsegmental PEs. Only one patient presented with right ventricle overload and pulmonary artery hypertension on echocardiogram.

It was possible to analyze DD variation over the course of the hospital stay in 11 of the 13 cases, which are illustrated in Figure 1. Only three (27.2\%) of the patients analyzed had DD levels below the reference values $(500 \mathrm{ng} / \mathrm{mL})$ at admission and only one patient had levels exceeding 3,000 at admission - in this case, DVT was already present.

We found that DD levels were above $3,000 \mathrm{ng} / \mathrm{mL}$ on the day attributed to VTE onset in $8(80 \%)$ patients and that these levels were statistically higher than the baseline admission levels $(p<0.05)$. On the day of hospital discharge, a statistically significant decrease was also observed in DD values $(p<0.05)$.

In this series, all patients $(100 \%)$ received pharmacological VTE prophylaxis or full anticoagulation, starting at admission. The institution's choice of pharmacological prophylaxis is low molecular weight heparin (LMWH) at $40 \mathrm{mg}$ once daily, unless contraindicated. When renal function precludes use of LMWH, unfractionated heparin (UFH) is employed. Mechanical prophylaxis (standard anti-embolism $13-18 \mathrm{mmHg}$ stockings or intermittent pneumatic compression devices) is administered in association with an anticoagulant for all critical patients. Mechanical prophylaxis is used in isolation when pharmacological prophylaxis is contraindicated.

In four cases $(30.7 \%)$, patients received full dose anticoagulation starting at admission because VTE was diagnosed at the first examination. In all other cases $(69.3 \%)$, patients were started on a prophylactic regimen at admission, until a confirmed VTE diagnosis provoked dosage change.

Mechanical prophylaxis was used as an adjuvant method in 11 patients $(84.6 \%)$, all of them critical: 10 in intensive care and 1 in the palliative care ward. In two cases, compressive stockings were used in isolation and in 9 cases in association with intermittent pneumatic compression devices.

Full anticoagulation therapy was started immediately after confirmation of VTE by imaging for 12 patients 


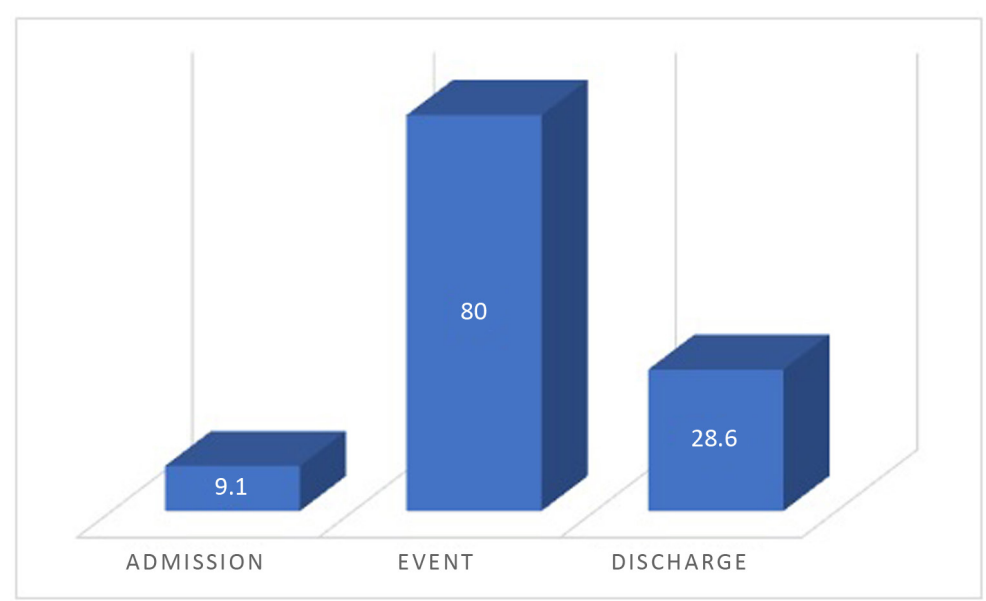

Figure 1. Percentages of patients with D-dimer levels $>3000 \mathrm{ng} / \mathrm{mL}$ at admission, on the day attributed to VTE onset, and after acute $\mathrm{V} T \mathrm{E}$ resolution.

(4 at admission and 8 later on during hospitalization). LMWH is the institution's drug of choice and was used in seven patients; five patients were given UFH due to renal impairment. One patient, who was in palliative care for an advanced neoplasm, was maintained on a prophylactic regimen.

Complications related to anticoagulation were observed in 4 of the 12 treated patients, with one type 1 complication (hematuria) and three type 2 complications (two cases of minor gastrointestinal bleeding and one case of hemoptysis), according to the Bleeding Academic Research Consortium definitions.

In one case, mechanical thrombectomy associated with thrombolysis was required due to massive PE. The procedure was successful and the patient was extubated 10 days after the procedure, with no signs of permanent clinical damage and unaltered echocardiogram at discharge.

The mean hospital stay was 33.4 days (ranging from 2 to 49 days). In patients in whom a VTE diagnosis was not present at first examination, median time from admission to VTE diagnosis was 14 days (ranging from 4 to 82 days). In-hospital VTE occurred in only one case in a ward setting and this was the palliative care patient. One patient presenting concomitant COVID-19 and DVT at admission remained stable throughout treatment with no need for intensive care. In all other cases, either patients were admitted directly to the ICU with DVT or DVT occurred while in the ICU.

Two deaths occurred during the study, both of patients who had severe comorbidities: one patient with advanced stage neoplasm and a second patient who had recently undergone cardiac surgery complicated by an infection. In one case of in-hospital death (50\%), the patient could not be given anticoagulation therapy due to an advanced neoplasm.
At the end of our study protocol, nine patients had been discharged and two remained hospitalized, but had no signs of worsening of their condition due to the VTE event, including the patient in palliative care. All nine discharged patients received oral anticoagulation for secondary VTE prophylaxis, as prescribed by their attending physicians: six of them received rivaroxaban, two received warfarin, and one received dabigatran.

\section{DISCUSSION}

In this series, out of 484 in-patients hospitalized due to COVID-19 infection in the clinical ward (stable patients) or in the ICU (severe patients), sixty-four (13.22\%) presented symptoms leading to investigation of DVT. Of these, $13(20.31 \% ; 2.7 \%$ overall) presented a confirmed case of VTE.

It has been well established that moderate to severe presentations of the SARS-CoV-2 infection may present with acute renal failure, severe hypoxia, and cardiac arrhythmias. ${ }^{13}$ The virus can cause damage through widespread pro-inflammatory cytokine responses, increased procoagulant factors leading to coagulation chain disorder and elevation of fibrin degradation products, thus raising DD levels. ${ }^{6}$

Based on this premise, VTE risks associated with COVID-19 have been fiercely discussed, with an assumption that these patients were exposed to increased risk of thromboembolic events. Several studies were conducted assessing the VTE prevalence in COVID-19 patients: most of them reported an incidence of over $20 \%{ }^{7,8,10,14-19}$ However, one study, conducted in China by Xu et al., ${ }^{11}$ found that $2.9 \%$ of COVID-19 patients developed VTE.

Expert consensus, however, still suggests against routine ultrasound screening for detection of asymptomatic 
DVT, even in critically ill COVID-19 patients. ${ }^{20}$ In the recent CHEST Guideline and Expert Panel Report it was noted that, although routine ultrasound screening is not recommended, clinicians ought to have a low threshold for imaging investigation with a reasonable degree of clinical suspicion for VTE. ${ }^{20}$ For this reason, at our institution, patients with COVID-19 were investigated even if Wells criteria were suggestive of low probability.

In four patients with severe disease, VTE was diagnosed immediately and they were directly referred to the ICU because of the diagnosis of simultaneous COVID-19 and VTE. The other nine patients were hospitalized with COVID-19 and developed VTE over the course of their hospital stays. In accordance with previous studies, most of our patients $(84.6 \%)$ developed VTE while in intensive care. Only two patients in our series were diagnosed with VTE while stable and in clinical wards. This predominance of VTE cases occurring in ICUs has been repeatedly observed in several series in the literature. ${ }^{7-9}$

The most frequent VTE risk factor in this series was obesity and overweight, noted in $76.9 \%$ of patients, which is also common in patients without COVID-19.21 Most patients presented two or more comorbidities, of which dyslipidemia, $\mathrm{SAH}$, and diabetes mellitus (DM) were the most common. These comorbidities are well-established factors for worsening of SARSCoV-2 infections and have a negative effect on patients' prognoses. Furthermore, COVID-19 may worsen preexisting heart conditions. ${ }^{9,21}$

With respect to DVT site, DVT was more frequent in the lower limbs. When DVT did occur in the upper limbs, it was invariably associated with current or previous use of central venous catheters and only one upper-limb DVT complicated with PE. The diminished incidence of PE in association with upper-limb DVT is in accordance with general population data. ${ }^{22}$ In a study published by Yamashita et al., ${ }^{23}$ the global prevalence of DVT in upper limbs was 3\%, with 58\% of these patients having been diagnosed with cancer and $22 \%$ being on central venous catheters, with a $14 \%$ rate of associated $\mathrm{PE} .^{23}$

Since Lippi et al. ${ }^{24}$ published an analysis that demonstrated a 2.5 fold increase in the DD values in patients with severe COVID-19, papers regarding this marker have abounded, including those proposing DD levels over 2,000 at hospital admission as an effective predictor of mortality. ${ }^{25}$ However, these findings are questionable, especially with regard to the difficulty of standardizing these tests. ${ }^{26}$ For this reason, our institution chose not to define the necessity of anticoagulation based solely on laboratory findings. Prophylaxis was offered on the same basis as for routine clinical inpatients, unless there were contraindications.
It has been established that a systematic in-hospital VTE prophylactic approach can greatly diminish the occurrence of thromboembolism. ${ }^{27,28}$ However, some studies suggest high prevalence of VTE in COVID-19 patients despite adequate prophylaxis. ${ }^{15,19}$ Even though our study is limited to patients who presented clinical symptoms, the prevalence of VTE events is far lower than that reported by recent studies. In one study of 138 consecutively enrolled COVID-19 patients, only $2.9 \%$ (4 patients) were effectively diagnosed with VTE, even though $16.67 \%$ were classified as highrisk according to the Padua Prediction Score. ${ }^{11}$ The authors attributed these findings to a consequence of effective thromboprophylaxis in patients classified as being at high risk of thrombosis. ${ }^{11}$

Only one patient presented with massive PE. He was a morbidly obese patient who was promptly treated by catheter directed thrombectomy and thrombolysis after presumptive PE diagnosis through an altered echocardiogram combined with a duplex scan finding of DVT. This patient had satisfactory progress and was discharged in good condition. The determination for early intervention as opposed to systemic thrombolysis is well endorsed in current literature, especially considering that the patient was at high risk for bleeding events. . $^{29,30}$

Only two deaths occurred from COVID-19 associated with VTE during the observation period. Both patients had severe comorbidities: one with advanced stage neoplasm and a second patient in recent recovery from cardiac surgery complicated with infection. Two patients over 90 years of age survived, demonstrating that these cases ought to be addressed individually and without prejudice.

This study is limited primarily by being a single center retrospective analysis, and also due to the fact that protocols for management of COVID-19 patients are not yet fully established, with lack of conduct standardization since this is not a totally elucidated disease.

Further multicenter research is needed for better understanding of the physiopathology of the association between COVID-19 and VTE,,, 32 enabling more accurate management and leading to better survival outcomes.

\section{CONCLUSION}

Overall symptomatic VTE prevalence in 484 hospitalized COVID-19 patients was 2.7\%, accounting for to $20.31 \%$ of patients who underwent imaging investigation after clinical suspicion. Thromboembolic events were more frequent in patients in intensive care.

Early institution of prophylaxis and immediate full anticoagulation when VTE is diagnosed should be the key goals for those who treat this type of patient. 


\section{REFERENCES}

1. Hunt BJ. Preventing hospital associated venous thromboembolism. BMJ. 2019;365:14239. http://dx.doi.org/10.1136/bmj.14239. PMid:31227478.

2. Darze ES, Casqueiro JB, Ciuffo LA, Santos JM, Magalhães IR, Latado AL. Pulmonary embolism mortality in Brazil from 1989 to 2010: gender and regional disparities. Arq Bras Cardiol. 2016;106(1):4-12. http://dx.doi.org/10.5935/abc.20160001. PMid:26559854.

3. Zerati AE, Wolosker N, Yazbek G, Langer M, Nishinari K. Vena cava filters in cancer patients: experience with 50 patients. Clinics. 2005;60(5):361-6. http://dx.doi.org/10.1590/S180759322005000500003. PMid:16254671.

4. Ramacciotti E, Agati LB, Aguiar VCR, et al. Zika and Chikungunya virus and risk for venous thromboembolism. Clin Appl Thromb Hemost. 2019;25:1-5. http://dx.doi.org/10.1177/1076029618821184. PMid:30808213.

5. World Health Organization. WHO disease outbreak news: nove Coronavirus - Republic of Korea (ex-China). 2020 [citado 2020 maio 28]. https://www.who.int/csr/don/21- january-2020-novel

6. Tang N, Li D, Wang X, Sun Z. Abnormal coagulation parameters are associated with poor prognosis in patients with novel coronavirus pneumonia. J Thromb Haemost. 2020;18(4):844-7. http://dx.doi. org/10.1111/jth.14768. PMid:32073213.

7. Lodigiani C, lapichino G, Carenzo L, et al. Venous and arterial thromboembolic complications in COVID-19 patients admitted to an academic hospital in Milan, Italy. Thromb Res. 2020;191:9-14. http://dx.doi.org/10.1016/j.thromres.2020.04.024. PMid:32353746.

8. Klok FA, Kruip MJHA, van der Meer NJM, et al. Incidence of thrombotic complications in critically ill ICU patients with COVID-19. Thromb Res. 2020;191:145-7. http://dx.doi.org/10.1016/j. thromres.2020.04.013. PMid:32291094.

9. LiB, Yang J, Zhao F, et al. Prevalence and impact of cardiovascular metabolic diseases on COVID-19 in China. Clin Res Cardiol. 2020;109(5):531-8. http://dx.doi.org/10.1007/s00392-020-01626-9. PMid:32161990.

10. Middeldorp S, Coppens $M$, van Haaps TF, et al. Incidence of venous thromboembolism in hospitalized patients with COVID-19. J Thromb Haemost. 2020;18(8):1995-2002. http://dx.doi.org/10.1111/ jth.14888. PMid:32369666.

11. Xu J, Wang L, Zhao L, et al. Risk assessment of venous thromboembolism and bleeding in COVID-19 patients. Res Sq. 2020. In press.

12. Wells PS, Anderson DR, Bormanis J, et al. Value of assessment of pretest probability of deep-vein thrombosis in clinical management. Lancet. 1997;350(9094):1795-8. http://dx.doi.org/10.1016/S01406736(97)08140-3. PMid:9428249.

13. Wang D, Hu B, Hu C, et al. Clinical characteristics of 138 hospitalized patients with 2019 novel coronavirus-infected pneumonia in Wuhan China. JAMA. 2020;323(11):1061-9. http://dx.doi.org/10.1001/ jama.2020.1585. PMid:32031570.

14. Chen S, Zhang D, Zheng T, Yu Y, Jiang J. DVT incidence and risk factors in critically ill patients with COVID-19. J Thromb Thrombolysis. 2021;51(1):33-9. http://dx.doi.org/10.1007/s11239-020-02181-w. PMid:32607652.

15. Artifoni M, Danic G, Gautier G, et al. Systematic assessment of venous thromboembolism in COVID - 19 patients receiving thromboprophylaxis : incidence and role of $\mathrm{D}$ - dimer as predictive factors. J Thromb Thrombolysis. 2020;50(1):211-6. http://dx.doi. org/10.1007/s11239-020-02146-z. PMid:32451823.

16. Zhang L, Feng $X$, Zhang D, et al. Deep vein thrombosis in hospitalized patients with COVID-19 in Wuhan, China: prevalence, risk factors, and outcome. Circulation. 2020;142(2):114-28. http://dx.doi. org/10.1161/CIRCULATIONAHA.120.046702. PMid:32421381.

17. Demelo-Rodríguez P, Cervilla-Muñoz E, Ordieres-Ortega L, et al. Incidence of asymptomatic deep vein thrombosis in patients with
COVID-19 pneumonia and elevated D-dimer levels. Thromb Res. 2020;192:23-6. http://dx.doi.org/10.1016/j.thromres.2020.05.018. PMid:32405101.

18. Di Minno A, Ambrosino P, Calcaterra I, Di Minno MND. COVID-19 and venous thromboembolism: a meta-analysis of literature studies. Semin Thromb Hemost. 2020;46(7):763-71. http://dx.doi. org/10.1055/s-0040-1715456. PMid:32882719.

19. Chi G, Lee JJ, Jamil A, et al. Venous thromboembolism among hospitalized patients with covid-19 undergoing thromboprophylaxis: a systematic review and meta-analysis. J Clin Med. 2020;9(8):2489. http://dx.doi.org/10.3390/jcm9082489. PMid:32756383.

20. Moores LK, Tritschler T, Brosnahan S, et al. Prevention, diagnosis, and treatment of VTE in patients with COVID-19. Chest. 2020;158(3):1143-63. http://dx.doi.org/10.1016/j.chest.2020.05.559. PMid:32502594.

21. Konstantinides SV, Meyer G, Becattini C, et al. 2019 ESC guidelines for the diagnosis and management of acute pulmonary embolism developed in collaboration with the European respiratory society (ERS). Eur Heart J. 2020;41(4):543-603. http://dx.doi.org/10.1093/ eurheartj/ehz405. PMid:31504429.

22. Kearon C, Akl EA, Ornelas J, et al. Antithrombotic therapy for VTE disease: CHEST guideline. Chest. 2016;149(2):315-52. http:// dx.doi.org/10.1016/j.chest.2015.11.026. PMid:26867832.

23. Yamashita $Y$, Morimoto $T$, Amano $H$, et al. Deep vein thrombosis in upper extremities: clinical characteristics, management strategies and long-term outcomes from the COMMAND VTE registry. Thromb Res. 2019;177:1-9. http://dx.doi.org/10.1016/j. thromres.2019.02.029. PMid:30825719.

24. Lippi G, Favaloro E. D-dimer is associated with severity of Coronavirus disease 2019: a pooled analysis. Thromb Haemost. 2020;120(5):876-8. http://dx.doi.org/10.1055/s-0040-1709650. PMid:32246450.

25. Zhang L, Yan X, Fan Q, et al. D-dimer levels on admission to predict in-hospital mortality in patients with COVID-19. J Thromb Haemost. 2020;18(6):1324-9. http://dx.doi.org/10.1111/jth.14859. PMid:32306492.

26. Favaloro EJ, Thachil J. Reporting of D-dimer data in COVID-19: some confusion and potential for misinformation. Clin Chem Lab Med. 2020;58(8):1191-9. http://dx.doi.org/10.1515/cclm-2020-0573. PMid:32432563.

27. Samama MM, Cohen AT, Darmon JY, et al. A comparison of enoxaparin with placebo for the prevention of venous thromboembolism in acutely ill medical patients. N Engl J Med. 1999;341(11):793-800. http://dx.doi.org/10.1056/NEJM199909093411103. PMid:10477777.

28. Kahn SR, Lim W, Dunn AS, et al. Prevention of VTE in nonsurgical patients: antithrombotic therapy and prevention of thrombosis, 9th ed: American College of Chest Physicians evidence-based clinical practice guidelines. Chest. 2012;141(2, Suppl.):e195S-226S. http://dx.doi.org/10.1378/chest.11-2296. PMid:22315261.

29. Gregorio M, Laborda A, de Blas I, Medrano J, Mainar A, Oribe M. Tratamiento endovascular mediante fibrinolisis y fragmentación del embolismo pulmonar masivo con instabilidad hemodinámica: experiencia de un solo centro en 111 pacientes. ¿Por qué no seguimos las recomendaciones de la ACCP? Arch Bronconeumol. 2011;47(1):1724. http://dx.doi.org/10.1016/j.arbres.2010.08.004. PMid:21208705.

30. Galastri F, Valle LGM, Affonso B, et al. COVID-19 complicated by pulmonary embolism treated with catheter directed thrombectomy. Vasa.2020;49(4):333-7. http://dx.doi.org/10.1024/0301-1526/a000880.

31. Rossi FH. Tromboembolismo venoso em pacientes COVID-19. J Vasc Bras. 2020;7301(19):1-5.

32. Sobreira ML, Marques MA. A panaceia dos anticoagulantes na infecção pela COVID-19. J Vasc Bras. 2020;7301(19):e20200063. http://dx.doi.org/10.1590/1677-5449.200063. 
Correspondence Maria Fernanda Cassino Portugal Av. Albert Einstein, 627, Bloco A1, $4^{\circ}$ andar, sala 423 - Morumbi CEP 05652-000 - São Paulo (SP), Brasil

Tel.: +55 (11) 3885-5361

E-mail: mafe.portugal@gmail.com

Author information

MJSC - Assistant Physician, Serviço de Radiologia Intervencionista, Hospital Israelita Albert Einstein. CAVP and AT - Assistant Physicians, Departamento de Radiologia, Hospital Israelita Albert Einstein.

JCCG - Coordinating Physician, Setor de Hematologia e Coagulação,

Departamento de Patologia Clínica, Hospital Albert Einstein; Assistant Professor, Pós-graduação estrito senso, Faculdade Israelita de Ciências da Saúde.

MFCP - Research fellow, Departamento de Cirurgia Vascular, Hospital Israelita Albert Einstein.

LJRF - Leading Physician, Departamento de Pacientes Graves, Hospital Israelita Albert Einstein.

NW - Full professor, Faculdade de Medicina, Faculdade Israelita de Ciências da Saúde Albert Einstein; Lecturer-Professor; Associate

Professor, Faculdade de Medicina, Universidade de São Paulo.

Author contributions Conception and design: NW, LJRF, JCCG Analysis and interpretation: MJSC, MFCP

Data collection: MJSC, MFCP, CAVP, AT Writing the article: MFCP, MJSC

Critical revision of the article: NW, LJRF, JCCG, CAVP, AT Final approval of the article*: MJSC, CAVP, JCCG, AT, MFCP, LJFR, NW Statistical analysis: MJSC Overall responsibility: NW

*All authors have read and approved of the final version of the article submitted to J Vasc Bras. 